\title{
Políticas de integração regional no governo Lula
}

Paulo Roberto de Almeida

\section{RESUMO:}

Apresentação e discussão da diplomacia regional do governo de Luis Inácio Lula da Silva, com exposição das principais questões inscritas na agenda diplomática do Brasil, multilateral e regional. $\mathrm{O}$ ensaio começa por identificar as fontes do pensamento do governo Lula nas posições exibidas historicamente pelo PT, ao longo de sua trajetória política, com transcrição de posições defendidas pelo candidato Lula nos três escrutínios presidenciais de que participou (1989, 1994 e 1998), antes de vencer as eleições em 2002. O trabalho focaliza, em seguida, vários aspectos da diplomacia regional do governo Lula, com destaque para as questões da "liderança regional” e seus reflexos nas relações com a vizinha Argentina, da consolidação e expansão (em grande parte frustradas) do Mercosul em direção de um “espaço integrado sul-americano”, consubstanciado na Comunidade Sul-Americana de Nações, e, finalmente, das negociações da Alca, até o momento inconclusas.

Palavras-chave: Diplomacia regional; Governo de Luis Inácio Lula da Silva; liderança regional

\section{Politics of regional integration in the Lula's government}

\section{ABSTRACT:}

Presentation and analysis of the regional diplomacy of Luis Inácio Lula da Silva’s government (2003-2006), with a brief description of the main issues of the Brazilian diplomatic agenda, either multilateral or regional. This historical essay starts by the identification of the main intellectual sources of the Workers Party thinking, and by the analysis of the foreign relations issues at the three presidential elections (1989, 1994 e 1998) in which Lula was candidate, before winning the elections of 2002. The paper then concentrates in the various aspects of Lula's regional diplomacy. Important questions are the "regional leadership" role for Brasil and its implications for the relationship with Argentina, the consolidation and expansion (still to become real) of Mercosur towards an "integrated South-American space”, as reflected in the South-American Community of Nations, and, finally, the FTAA negotiations, unfinished up to now.

Keywords: Regional diplomacy; Luis Inácio Lula da Silva’s government; regional leadership 


\section{Introdução: da “diplomacia presidencial” à “diplomacia partidária”}

Entre todas as políticas governamentais - macroeconômicas ou setoriais - que têm sido anunciadas, tentativamente formuladas ou efetivamente implementadas desde o início do atual mandato do presidente Luís Inácio Lula da Silva, em $1^{\circ}$ de janeiro de 2003, nenhuma consegue, com mais fidelidade, refletir as idéias, interpretar os valores e reproduzir as prioridades do seu movimento político, o Partido dos Trabalhadores (PT), do que a política externa. Com efeito, em nenhuma das diversas políticas setoriais - com a possível exceção da reforma agrária, mas aqui com diversas carências operacionais -, nem, a mais forte razão, na política macroeconômica, lato sensu, pode-se registrar, como no terreno das relações exteriores, tal identidade de propósitos e de intenções entre, por um lado, o proclamado e o tendencialmente realizado pelo governo Lula, e, de outro, aquilo que sempre pregou, desde sua fundação, e continuou pregando, durante anos a fio, o PT. No terreno da política externa, em especial, nenhuma outra área está tão ligada, histórica e indissociavelmente, aos programas e práticas do PT como a diplomacia regional, na qual se destaca em particular a integração no Mercosul e da América do Sul.

O governo Lula tinha iniciado seu mandato com fortes e incisivas críticas ao governo anterior - em dois mandatos sucessivos, de 1995 a 1998 e de 1999 a 2002 - do presidente Fernando Henrique Cardoso, censurado inclusive, no que toca ao modus operandi de suas relações exteriores, no que se refere à “diplomacia presidencial” que foi explícita e reconhecidamente praticada pelo chefe de Estado. Ainda que não tenha adotado o conceito, provavelmente em virtude de sua aberta vinculação com as práticas da administração anterior nesse terreno, o governo Lula retomou e ampliou sua amplitude e intensidade, praticando como nenhum outro governo do Brasil o engajamento direto do chefe de Estado nas conversações diplomáticas e nas iniciativas de política externa, seja no plano bilateral, seja no âmbito regional ou multilateral.

Em razão, precisamente, da já referida identidade entre a política externa prática e as políticas preconizadas pelo PT, pode-se talvez adiantar que, nessa área, mais do que uma "diplomacia presidencial”, se está assistindo, de fato, a uma verdadeira "diplomacia partidária”, inclusive em virtude da unanimidade que a política externa do governo Lula recolhe junto às diferentes tendências e grupos internos do PT, o que manifestamente não 
ocorre em relação à política econômica ou em relação a diversas outras políticas setoriais do governo, geralmente recebidas com reservas nos setores mais à esquerda do partido. Essa constatação é ainda mais verdadeira e enfática no que se refere à política externa especificamente voltada para o âmbito regional, seja no terreno da integração, seja ainda no diálogo político e na coordenação de posições com determinados governos da região, alegadamente identificados ao campo progressista ou antiimperialista, como é natural que ocorra num partido identificado com essas correntes políticas como é o PT.

Tendo já discorrido sobre a diplomacia do governo Lula de uma forma geral, inclusive em sua dimensão comparada com a da administração anterior, ${ }^{1}$ pretendo concentrar-me, neste ensaio, sobre as principais características, os fundamentos políticos e as modalidades de implementação da diplomacia regional desse governo, com eventual referência aos demais aspectos de sua política externa como um todo. A documentação de referência pode ser facilmente encontrada nos sites oficiais de material governamental, com destaque para os sites do Ministério das Relações Exteriores, da própria Presidência da República ou da Radiobrás (que reproduz, em adição aos discursos oficiais inseridos nos dois primeiros, intervenções orais, de improviso, do presidente). Ela pode ser complementada pelo abundante material da imprensa diária, que oferece uma cobertura satisfatória da diplomacia do governo Lula e que será utilizada de modo seletivo neste ensaio. A abordagem será historicamente linear, com destaque para os eixos temáticos da integração e das negociações comerciais, o que aliás impõe começar pelas posições ostentadas historicamente pelo PT, programaticamente e nas campanhas eleitorais nas quais o partido concorreu com candidato à presidência, como forma de comprovar a assertiva da “diplomacia partidária”.

\section{Nas origens: a luta contra o imperialismo e o capitalismo internacional}

O manifesto de fundação do PT, resultante de seu $1^{\circ}$ Encontro Nacional, em 1981, ressalta, na parte que pode ser considerada como de "política externa”, sua "solidariedade

\footnotetext{
${ }^{1}$ Ver Paulo Roberto de Almeida, “Uma política externa engajada: a diplomacia do governo Lula”, Revista Brasileira de Política Internacional (Brasília: IBRI, ano 47, nº 1, 2004, pp. 162-184); disponível no link: http://www.pralmeida.org/05DocsPRA/1260PExtLula.pdf.
} 
à luta de todas as massas oprimidas do mundo". ${ }^{2}$ Em seu programa, o PT "defende uma política internacional de solidariedade entre os povos oprimidos e de respeito mútuo entre as nações que aprofunde a cooperação e sirva à paz mundial. O PT apresenta com clareza sua solidariedade aos movimentos de libertação nacional”. Não consta do programa menção explícita à "política externa”, mas, o "plano de ação" de 1981 contemplava os seguintes pontos em seu item VI: "Independência Nacional: contra a dominação imperialista; política externa independente; combate a espoliação pelo capital internacional; respeito à autodeterminação dos povos e solidariedade aos povos oprimidos".

Na campanha presidencial de 1989, candidato do PT pela primeira vez, Lula, apresentou um amplo e abrangente programa de governo e, na linha das resoluções políticas adotadas pelo partido em seu IV Encontro Nacional (junho de 1989), pretendia propor uma "política externa independente e soberana, sem alinhamentos automáticos, pautada pelos princípios de autodeterminação dos povos, não-ingerência nos assuntos internos de outros países e pelo estabelecimento de relações com governos e nações em busca da cooperação à base de plena igualdade de direitos e benefícios mútuos”. ${ }^{4}$ Mesmo se esses princípios não diferiam muito da política externa efetivamente seguida pelo Brasil, ainda assim uma vitória do candidato-trabalhador, representaria uma reavaliação radical das posturas brasileiras na área, já que a "Frente Brasil Popular" prometia adotar uma "política antiimperialista, prestando solidariedade irrestrita às lutas em defesa da autodeterminação e da soberania nacional, e a todos os movimentos em favor da luta dos trabalhadores pela democracia, pelo progresso social e pelo socialismo”. Um hipotético governo da Frente defenderia a "luta dos povos oprimidos da América Latina" e Lula

\footnotetext{
2 Partido dos Trabalhadores, Programa, manifesto, estatuto. Brasília: Centro de Documentação e Informação da Câmara dos Deputados, 1984, Manifesto, p. 5-7.

${ }^{3}$ Idem, Programa, p. 9-13 e Plano de Ação, p. 14-15.

${ }^{4}$ Para uma abordagem das posições programáticas e eleitorais do PT ver Paulo Roberto de Almeida, Relações internacionais e política externa do Brasil: história e sociologia da diplomacia brasileira. $2^{\mathrm{a}}$ edição, Porto Alegre: Editora da UFRGS, 2004, capítulos 6 e 7, respectivamente: “A política da política externa: o papel dos partidos políticos" e "A política externa nas campanhas presidenciais, de 1989 a 2002, e a diplomacia do governo Lula”, pp. 187-254 e 255-308.
} 
chegou mesmo a propor a “decretação de uma moratória unilateral para 'solucionar' a questão da dívida externa”. ${ }^{5}$

Alguns meses depois da campanha presidencial de 1989, o líder do PT anunciou, em coalizão com alguns outros partidos de esquerda que tinham feito parte de sua coalizão eleitoral, a formação de um "governo paralelo", experiência que não chegou realmente a frutificar, pelo menos no que se refere à atividade de um "ministro paralelo" das relações exteriores. Em todo caso, o PT patrocinou logo em seguida, em São Paulo, a criação de um "foro" de partidos de esquerda da América Latina, que depois se consolidou como reunião periódica de formações “progressistas” da região e contrárias às supostas ou reais políticas "neoliberais” de estabilização econômica no continente. Dele sempre fizeram parte o Partido Comunista de Cuba e as Forças Armadas Revolucionárias de Colômbia (FARC), ademais de outras agrupações políticas de esquerda, inclusive de caráter guerrilheiro, da América Latina.

O PT foi também o partido que primeiro definiu um programa de governo para a campanha presidencial de 1994, com propostas bem articuladas, mas por vezes contraditórias, que refletiam um intenso debate interno entre as diversas correntes do partido. O "Governo Democrático e Popular" que resultaria se sua coalizão fosse eleita propunha desenvolver uma política externa que buscaria "simultaneamente uma inserção soberana do Brasil no mundo e a alteração das relações de força internacionais contribuindo para a construção de ordem mundial justa e democrática” ${ }^{6}$ O programa de então já destacava como áreas prioritárias da "nova política externa" a América Latina e o Mercosul. Ele não deixava de dar ênfase às "relações de cooperação econômica e nos domínios científico e tecnológico, com uma correspondente agenda política”, na esfera Sul-Sul, com países como a China, Índia, Rússia e África do Sul e com os países de língua portuguesa. Algumas iniciativas internacionais eram listadas, como, por exemplo, a "rediscussão dos problemas das dívidas externas dos países periféricos”, propostas sobre a fome e a miséria no mundo ou ainda a convocação de uma conferência

\footnotetext{
${ }^{5}$ Cf. GPRI - Grupo de Pesquisas em Relações Internacionais, A política externa nas plataformas dos candidatos a presidente do Brasil em 1989, Brasília: Universidade de Brasília, texto processado, dezembro de 1989, p. 55-56.

${ }^{6}$ Cf. Partido dos Trabalhadores, Programa de Governo, in Teoria e Debate, São Paulo: Fundação Perseu Abramo, nº 24, março-abril-maio de 1994, caderno especial, pp. 29 e 30.
} 
internacional - "de porte semelhante à ECO-92” - para discutir a situação do trabalho no mundo e medidas efetivas contra o desemprego.

A terceira candidatura presidencial de Lula, em 1998, foi feita mediante a coalizão "União do Povo Muda Brasil" - com o PDT, o PCdoB, o PSB e o PCB -, cujas "diretrizes de governo" acusavam o governo FHC de ter praticado uma abertura "irresponsável” da economia e de ter desnacionalizado a "nossa indústria e nossa agricultura, provocando desemprego e exclusão social”. A ênfase na perda de soberania econômica do país era o ponto forte da campanha de Lula na área internacional, elemento combinado a uma política externa que se propunha mudar a forma de inserção do Brasil no mundo. O Ponto 12 das diretrizes, "Presença soberana no mundo", defendia uma "política externa, fundada nos princípios da autodeterminação", que "expressará nosso desejo” de ver o Brasil atuar "com decisão visando alterar as relações desiguais e injustas que se estabeleceram internacionalmente”. Ainda na mesma linha, um governo liderado pelo PT lutaria "por mudanças profundas nos organismos políticos e econômicos mundiais, sobretudo a ONU, o FMI e a OMC”. Documento liberado quando do agravamento da crise financeira, em princípios de setembro de 1998, avançava a proposta de "participar da construção de novas instituições financeiras internacionais", uma vez que "as atualmente existentes - FMI, OMC, BIRD - são incapazes de enfrentar a crise".

De maneira mais positiva, o programa enfatizava a intenção de fortalecer as relações do Brasil com os outros países do Sul, "em especial com os da América Latina, da África meridional e os de expressão portuguesa”. O processo de integração subregional, finalmente, era visto muito positivamente, mas ficava claro o desejo de efetuar uma "ampliação e reforma do Mercosul que reforce sua capacidade de implementar políticas ativas comuns de desenvolvimento e de solução dos graves problemas sociais da região". O Mercosul era aparentemente considerado como uma espécie de "bastião antiimperialista”, em contraposição aos projetos norte-americanos de diluir esse esquema num vasto empreendimento livre-cambista do Alasca à Terra do Fogo, como proposto na iniciativa da Área de Livre Comércio das Américas (Alca). De forma geral, a Alca se apresentava como um anátema na política externa de um governo liderado pelo PT, perdendo apenas em importância na escala de inimigos ideológicos para o neoliberalismo e a globalização capitalista promovida pelas grandes empresas multinacionais. 
Na campanha de 2002, que se desenvolveu sob o impacto da crise financeira deslanchada pela moratória Argentina, com a conseqüente necessidade de o Brasil contrair mais um pacote de ajuda financeira preventiva junto ao FMI, o candidato Lula continuou a condenar de forma veemente a "submissão" do governo brasileiro aos “ditames” do FMI e sua abertura ao “capital internacional”, mas a retórica já não escondia uma posição mais pragmática em relação aos investimentos diretos estrangeiros. O PT, aliás, contava com uma coalizão que incluía desta vez um pequeno partido de “direita”, o Partido Liberal (PL), que forneceu o candidato à vice-presidência. O candidato Lula foi bastante cuidadoso na exposição de suas idéias, ainda que algumas delas, no início da campanha, tenham sido exploradas pelos adversários (como o apoio às políticas subvencionistas da agricultura européia ou a proposta de que o Brasil deveria deixar de exportar alimentos até que todos os brasileiros pudessem se alimentar de maneira conveniente).

Na primeira fase da campanha, Lula ainda repetia velhos bordões do passado (contra o FMI e a Alca, por exemplo), que depois foram sendo corrigidos ou alterados para acomodar novas realidades e a coalizão com grupos moderados. Essa estratégia que tinha sido definida pelas lideranças do PT, a começar pelo próprio Lula, praticamente no imediato seguimento da frustrada campanha de 1998 - foi implementada de forma consistente, o que permitiu ampliar a audiência do candidato, trazendo-o mais para o centro do espectro político.

Até dezembro de 2001, no entanto, quando foi realizado em Pernambuco o XII Encontro Nacional do PT, o partido e o candidato pareciam propensos a continuar defendendo as mesmas teses adotadas e disseminadas ao longo dos anos 1980 e 1990, quando o ataque genérico ao neoliberalismo e à abertura comercial eram de rigor, com o repetido recurso a velhos refrões do passado. Em relação à Alca, por exemplo, o encontro de Olinda aprovou a resolução da Câmara dos Deputados - apresentada por iniciativa do deputado Aloísio Mercadante - no sentido de pedir a imediata suspensão das negociações e de submeter o tema ao exame do Fórum Social Mundial de Porto Alegre e à sociedade civil, “culminando com a convocação de um plebiscito a respeito”. Demandas típicas nessas moções aprovadas em encontros como o de Olinda, sempre colocadas no âmbito da “ruptura necessária”, eram constituídas pela luta contra o “neoliberalismo 
globalizado", o apoio ao "movimento em defesa da taxa Tobin", o "cancelamento das dívidas externas dos países pobres" (acompanhada pela "auditoria e renegociação das dívidas públicas externas dos demais países do 'terceiro mundo'”) e o "estabelecimento mecanismos de autodefesa contra o capital externo especulativo". A Alca, obviamente, era vista como "um projeto de anexação política e econômica da América Latina, cujo alvo principal, pela potencialidade de seus recursos e do seu mercado interno, é o Brasil.”

Em matéria de política externa, a intenção era a de ampliar as relações do Brasil com outros grandes países em desenvolvimento, sendo invariavelmente citados a China, a Índia e a Rússia. No terreno econômico, o compromisso era o de diminuir o grau de dependência financeira externa do Brasil, mobilizando para tal uma política de promoção comercial ativa, com novos instrumentos para alcançar tal finalidade. Vários outros elementos constitutivos de um programa mais realista de políticas públicas, globais e setoriais, passaram por uma revisão cuidadosa por parte de uma seleta equipe de assessores no decorrer do primeiro semestre de 2002, resultando num documento de compromissos que buscou consolidar a evolução do PT em direção da "governabilidade".

Segundo a "Carta ao Povo Brasileiro", divulgada por Lula em 22 de junho de 2002, o povo brasileiro quer "trilhar o caminho da redução de nossa vulnerabilidade externa pelo esforço conjugado de exportar mais e de criar um amplo mercado interno de consumo de massas". De maneira ainda mais enfática, nesse documento, Lula afirmou claramente que a "premissa dessa transição será naturalmente o respeito aos contratos e obrigações do País”, numa primeira manifestação formal em favor da continuidade de algumas das políticas seguidas pelo governo em vigor. ${ }^{7}$

Depois de algumas ameaças iniciais de retirar o Brasil das negociações da Alca (que seria “mais um projeto de anexação aos Estados Unidos do que de integração”), Lula passou a não mais rejeitar os pressupostos do livre-comércio, exigindo apenas que ele fosse pelo menos equilibrado, e não distorcido em favor do parceiro mais poderoso, o que constituiu notável evolução em relação a afirmações de poucas semanas antes. De forma geral, o tom anterior de recriminações e críticas, contendo manifestações de recusa ou negativas em relação aos "mercados", às instituições financeiras internacionais e às

\footnotetext{
7 Os documentos da campanha de 2002 foram divulgados no website oficial do candidato Lula, www.lula.org.br; depois passaram a estar disponíveis, em sua maior parte, no site do PT: www.pt.org.br.
} 
políticas dos Estados Unidos, passou a ser mais medido e equilibrado, revelando uma real preocupação com a governabilidade e o relacionamento externo, numa perspectiva de possibilidades reais de vitória nas eleições de outubro de 2002.

Em relação às negociações comerciais hemisféricas, por exemplo, o principal assessor econômico do candidato, deputado Aloísio Mercadante foi bastante cauteloso na qualificação das eventuais vantagens da Alca: "Esta não deve ser vista como uma questão ideológica ou de posicionamento pró ou contra os Estados Unidos, mas sim como um instrumento que pode ou não servir aos interesses estratégicos brasileiros” (Valor Econômico, 15.07.02). Trata-se, em todo caso, de notável evolução em relação à atitude exibida menos de um ano antes pelo mesmo deputado ao propor, na tribuna da Comissão de Relações Exteriores da Câmara dos Deputados, uma moção (apresentada em 12 de dezembro de 2001) no sentido de conclamar o governo brasileiro a se retirar das negociações da Alca, caso o Senado dos Estados Unidos ratificasse as condições estabelecidas pela Câmara de Representantes daquele país (o que aquele Senado fez, de forma aberta, mantendo as mesmas restrições já presentes no projeto da Câmara).

Os contatos mantidos pela cúpula do PT, no Brasil e no exterior, com industriais, banqueiros e investidores estrangeiros tendiam todos a confirmar esse novo realismo diplomático, e sobretudo econômico, do candidato. De fato, os principais dirigentes do PT começaram, em plena campanha, a se afastar cautelosamente da proposta feita pela CUT, pelo MST e pela CNBB, entre outros órgãos, de realizar um plebiscito nacional sobre a Alca, uma vez que se percebeu que ele teria resultados mais do que previsíveis, todos negativos para a continuidade dessas negociações e para a imagem pública que o partido pretendia projetar doravante.

De modo concordante com esse novo realismo, o Secretário de Relações Internacionais, Aloísio Mercadante, começou a aventar a possibilidade de um acordo comercial bilateral com os Estados Unidos, sem explicar como e em que condições ele poderia ser mais favorável do que o processo hemisférico, no qual o Brasil participa no âmbito do Mercosul. Em suas palavras: "é importante que, independentemente da Alca, o Brasil e os Estados Unidos iniciem um processo de negociação bilateral direcionado para a ampliação do seu intercâmbio comercial e a distribuição mais justa de seus 
benefícios” ${ }^{8}$ O PT parecia assim ter iniciado, ainda que de maneira hesitante, o caminho em direção ao reformismo moderado.

O programa oficial de campanha divulgado pelo candidato em 23 de julho de 2002 era bastante ambicioso quanto aos objetivos em matéria de política externa, uma vez que prometia convertê-la, como já tinha ocorrido com as plataformas anteriores, num dos esteios do processo de desenvolvimento nacional: “A política externa será um meio fundamental para que o governo implante um projeto de desenvolvimento nacional alternativo, procurando superar a vulnerabilidade do País diante da instabilidade dos mercados financeiros globais. Nos marcos de um comércio internacional que também vem sofrendo restrições em face do crescente protecionismo, a política externa será indispensável para garantir a presença soberana do Brasil no mundo.”

De fato, o candidato Lula se propunha uma tarefa de transformação do mundo e do continente sul-americano a partir de uma alavanca diplomática, o que poderia denotar certo excesso de otimismo quanto aos limites impostos pela realidade internacional a grandes projetos mudancistas no cenário externo, sobretudo vindos de um país dotado de recursos externos limitados como o Brasil. De toda forma, as intenções eram claras:

Uma nova política externa deverá [...] contribuir para reduzir tensões internacionais e buscar um mundo com mais equilíbrio econômico, social e político, com respeito às diferenças culturais, étnicas e religiosas. A formação de um governo comprometido com os interesses da grande maioria da sociedade, capaz de promover um projeto de desenvolvimento nacional, terá forte impacto mundial, sobretudo em nosso Continente. Levando em conta essa realidade, o Brasil deverá propor um pacto regional de integração, especialmente na América do Sul. Na busca desse entendimento, também estaremos abertos a um relacionamento especial com todos os países da América Latina.

O candidato Lula era o mais entusiástico promotor do Mercosul, mas ainda aqui com pouco realismo em relação às chances de uma moeda comum no curto prazo ou no que tange a implantação de instituições mais avançadas:

É necessário revigorar o Mercosul, transformando-o em uma zona de convergência de políticas industriais, agrícolas, comerciais, científicas e tecnológicas, educacionais e culturais. Reconstruído, o Mercosul estará apto para enfrentar desafios macroeconômicos, como os de uma política monetária comum. Também terá melhores condições para enfrentar os desafios do mundo globalizado. Para tanto, é fundamental

\footnotetext{
${ }^{8}$ Ver "Mercadante propõe acordo com os EUA”, Gazeta Mercantil, 22 de novembro de 2002.
} 
que o bloco construa instituições políticas e jurídicas e desenvolva uma política externa comum.

Persistia, igualmente, no programa, a atitude de princípio contrária à Alca e certo equívoco quanto aos objetivos de uma zona de livre-comércio, pois que se via nesse processo a necessidade do estabelecimento de políticas compensatórias, quando são raros os exemplos de acordos de simples liberalização de comércio que contemplem tais tipos de medidas corretivas:

Essa política em relação aos países vizinhos é fundamental para fazer frente ao tema da Área de Livre-Comércio das Américas (Alca). O governo brasileiro não poderá assinar o acordo da Alca se persistirem as medidas protecionistas extra-alfandegárias, impostas há muitos anos pelos Estados Unidos. [...] A política de livre-comércio, inviabilizada pelo governo norte-americano com todas essas decisões, é sempre problemática quando envolve países que têm Produto Interno Bruto muito diferentes [sic] e desníveis imensos de produtividade industrial, como ocorre hoje nas relações dos Estados Unidos com os demais países da América Latina, inclusive o Brasil. A persistirem essas condições a Alca não será um acordo de livre-comércio, mas um processo de anexação econômica do Continente, com gravíssimas conseqüências para a estrutura produtiva de nossos países, especialmente para o Brasil, que tem uma economia mais complexa. Processos de integração regional exigem mecanismos de compensação que permitam às economias menos estruturadas poder tirar proveito do livre-comércio, e não sucumbir com sua adoção. As negociações da Alca não serão conduzidas em um clima de debate ideológico, mas levarão em conta essencialmente o interesse nacional do Brasil.

O governo do PT também pretendia conduzir uma "aproximação com países de importância regional, como África do Sul, Índia, China e Rússia”, com o objetivo de “construir sólidas relações bilaterais e articular esforços a fim de democratizar as relações internacionais e os organismos multilaterais como a Organização das Nações Unidas (ONU), o Fundo Monetário Internacional (FMI), a Organização Mundial do Comércio (OMC) e o Banco Mundial”. Por outro lado, a antiga desconfiança em relação ao capital estrangeiro cedeu lugar a uma postura mais equilibrada, uma vez que se afirmou no programa de 2002 que o Brasil "não deve prescindir das empresas, da tecnologia e do capital estrangeiro”, alertando então que os “países que hoje tratam de desenvolver seus mercados internos, como a Índia e a China, não o fazem de costas para o mundo, dispensando capitais e mercados externos”. 
Dessa forma, o candidato do PT realizou, no espaço de poucos meses em 2002, um percurso em direção de uma postura mais realista no campo da política externa, assim como no terreno mais geral das políticas econômicas, notadamente no que se refere ao relacionamento com o capital e os investidores estrangeiros e com as instituições financeiras internacionais. Cabe registro, em todo caso, ao acolhimento, não totalmente desfavorável, feito por Lula em relação ao acordo anunciado pelo governo de mais um pacote de sustentação financeira por parte do FMI, desta vez pela soma inédita de 30 bilhões de dólares. A nota divulgada pela campanha de Lula na ocasião foi bastante cautelosa no que se refere ao cumprimento das obrigações externas, ainda que registrando negativamente o encargo passado ao governo futuro de manter um superávit primário na faixa de pelo menos 3,75\% do PIB até 2004. Ao encontrar-se com o presidente FHC, a pedido deste, para tratar da questão do acordo com o FMI, em 19 de agosto, o candidato do PT reiterava seu entendimento de que as dificuldades decorriam do "esgotamento do atual modelo econômico", confirmando também, com franqueza, seu compromisso afirmado na "Carta ao Povo Brasileiro" de que, "se vencermos as eleições começaremos a mudar a política econômica desde o primeiro dia”.

Não obstante, Lula oferecia uma série de sugestões para, no seu entendimento, “ajudar o País a sair da crise”, muitas delas medidas de administração financeira, de política comercial e de reativação da economia. O PT e seu candidato das três disputas anteriores se esforçavam, dessa forma, em provar aos interlocutores sociais - eleitores brasileiros - e aos observadores externos - capitalistas estrangeiros e analistas de Wall Street - que o partido e seus aliados estavam plenamente habilitados a assumir as responsabilidades governamentais e a representar os interesses externos do País com maior dose de realismo econômico e diplomático do que tinha sido o caso nas experiências precedentes. Essa estratégia se revelou benéfica ao candidato, que venceu amplamente no primeiro turno, ainda que de maneira não definitiva, habilitando-o depois a um sucesso estrondoso no segundo turno. 


\section{Preparando-se para o poder: a nova postura na agenda externa}

A eleição do candidato do PT à Presidência da República, depois de três tentativas anteriores, representou uma grande mudança no panorama social, econômico e político brasileiro. ${ }^{9}$ Mudanças foram prometidas nas esferas do sistema político e da economia e também no âmbito da política externa. Diversos sinais foram dados nesse sentido, desde antes da própria campanha eleitoral e no seu imediato seguimento, como as viagens, em dezembro de 2002, do presidente eleito ao imediato entorno regional (Argentina e Chile) e aos Estados Unidos, e de uma primeira missão oficiosa à Venezuela do assessor designado para temas de política internacional, professor Marco Aurélio Garcia, durante muitos anos Secretário de Relações Internacionais do PT, que tinha anunciado, aliás, novas linhas de política externa para o Brasil. ${ }^{10}$ Ainda assim, a escolha presidencial para ministro das relações exteriores recaiu num representante da diplomacia profissional, o embaixador Celso Amorim, já chanceler no governo Itamar Franco (de meados de 1993 ao final de 1994).

Interrogações persistiam quanto aos principais componentes da política externa do novo governo, se mais situadas na linha do que tinham pregado o programa, as resoluções oficiais e os próprios líderes do PT, ou se mais próximas das posições tradicionais da diplomacia brasileira, obviamente mais cautelosas em diversas vertentes de interesse nacional. Presumia-se que o novo governo atuaria com muito tato e realismo na frente diplomática, ainda que procurando igualmente impulsionar alguns dos temas caros à antiga agenda internacional do PT, feita de algumas opções preferenciais pelas chamadas forças progressistas e contestadoras de uma ordem mundial dominada pelos países capitalistas avançados, mas temperando-as com o pragmatismo que seria de se esperar de um governo estabelecido. Essa postura foi confirmada no primeiro pronunciamento do presidente eleito, em 28 de outubro de 2002. ${ }^{11}$ Nesse texto, consciente da gravidade da crise econômica e dos focos de tensão externa remanescente, Lula advertiu:

\footnotetext{
${ }^{9}$ Para uma análise do processo de transição do sistema político brasileiro e das implicações econômicas da transformação em curso, ver Paulo Roberto de Almeida, A grande mudança: conseqüências econômicas da transição política no Brasil. São Paulo: Editora Códex, 2003.

${ }^{10}$ Ver Marco Aurélio Garcia, “Assessor da Presidência da República aponta os eixos da política externa do governo Lula”, boletim da ADB. Brasília: Associação dos Diplomatas Brasileiros, ano X, n. 42, janeiromarço 2003, p. 16-22.

${ }^{11}$ Ver Luís Inácio Lula da Silva, “Compromisso com a campanha” in: www.lula.org.br, acesso em 29.10.2002.
} 
O Brasil fará a sua parte para superar a crise, mas é essencial que além do apoio de organismos multilaterais, como o FMI, o BID e o BIRD, se restabeleçam as linhas de financiamento para as empresas e para o comércio internacional. Igualmente relevante é avançar nas negociações comerciais internacionais, nas quais os países ricos efetivamente retirem as barreiras protecionistas e os subsídios que penalizam as nossas exportações, principalmente na agricultura.

A "nova diplomacia” não parecia afastar-se muito da "velha”, com talvez uma afirmação mais enfática dos interesses nacionais e da defesa da soberania:

É uma boa hora para reafirmar um compromisso de defesa corajosa de nossa soberania regional. E o faremos buscando construir uma cultura de paz entre as nações, aprofundando a integração econômica e comercial entre os países, resgatando e ampliando o Mercosul como instrumento de integração nacional e implementando uma negociação soberana frente à proposta da Alca. Vamos fomentar os acordos comerciais bilaterais e lutar para que uma nova ordem econômica internacional diminua as injustiças, a distância crescente entre países ricos e pobres, bem como a instabilidade financeira internacional que tantos prejuízos tem imposto aos países em desenvolvimento Nosso governo será um guardião da Amazônia e da sua biodiversidade. Nosso programa de desenvolvimento, em especial para essa região, será marcado pela responsabilidade ambiental.

Em outros termos, abandonou-se a tese da Alca "anexacionista" em favor de uma negociação séria dos interesses brasileiros nesses acordos de liberalização comercial. A defesa do multilateralismo, por outro lado, não destoa, em praticamente ponto nenhum, das conhecidas posições defendidas tradicionalmente pela diplomacia brasileira:

Queremos impulsionar todas as formas de integração da América Latina que fortaleçam a nossa identidade histórica, social e cultural. Particularmente relevante é buscar parcerias que permitam um combate implacável ao narcotráfico que alicia uma parte da juventude e alimenta o crime organizado. Nosso governo respeitará e procurará fortalecer os organismos internacionais, em particular a ONU e os acordos internacionais relevantes, como o protocolo de Quioto, e o Tribunal Penal Internacional, bem como os acordos de não proliferação de armas nucleares e químicas. Estimularemos a idéia de uma globalização solidária e humanista, na qual os povos dos países pobres possam reverter essa estrutura internacional injusta e excludente.

A incorporação do conceito de "globalização solidária” e o seu contrário, a tomada de posição contrária à “globalização assimétrica”, tinham freqüentado os discursos de Fernando Henrique Cardoso desde vários anos, da mesma forma como 
várias das demais propostas feitas nos terrenos da reforma das instituições multilaterais, da regulação dos capitais voláteis - inclusive com a adesão à chamada Tobin Tax - ou de eliminação do protecionismo comercial dos países desenvolvidos. Ainda assim, assistiuse nessa fase a uma série de críticas dirigidas contra as políticas da equipe FHC: falta de agressividade comercial, falta de prioridade ao Mercosul e à América do Sul e outras do gênero, o que mereceu pronta resposta do então chanceler Celso Lafer, sublinhando este, justamente, as iniciativas tomadas nessas áreas.

As manifestações retóricas começaram então a ser testadas na prática, à medida que o presidente eleito tomava conhecimento dos dossiês e passava a lidar diretamente com os problemas da agenda externa do Brasil. Isso ocorreu rapidamente, por exemplo, no caso do discurso (até então genérico) em favor da "revitalização" do Mercosul e de sua ampliação até incorporar plenamente o Chile e outros parceiros da América do Sul. Antes de sua primeira viagem como presidente eleito aos parceiros do Cone Sul, em dezembro, Lula chegou a exibir certo otimismo quanto à sua capacidade política em "resolver" os problemas do bloco, desconhecendo, aparentemente, os graves problemas estruturais, institucionais e conjunturais que se escondiam atrás das deficiências do processo integracionista, como por exemplo as perfurações da Tarifa Externa Comum, as salvaguardas ilegais aplicadas pelos países, a deficiente internalização dos regulamentos comuns e outros mais. A intenção de acolher o Chile como membro pleno do bloco, em particular, chocou-se com a realidade econômica de um país reconhecidamente aberto, isto é, "neoliberal” assumido, em busca de um acordo de livre-comércio com os Estados Unidos (e com quem mais estivesse disposto a aceitar acordos de abertura econômica e de liberalização comercial).

Da mesma forma, a tentativa do assessor diplomático do presidente eleito, Marco Aurélio Garcia, de intermediar a crise política na Venezuela, mediante viagem de contato e conversações em dezembro de 2002 (ainda antes da posse, portanto), teve igualmente de confrontar-se aos dados da realidade local, com certo desgaste diplomático para o Brasil, rapidamente reparado pelo novo chanceler a partir de sua posse. Estes dois exemplos constituíram os primeiros testes, ainda que parciais, acerca das possibilidades e limites da mera vontade política em matéria diplomática, terreno no qual os dados estruturais e a capacidade de "intervenção" do Brasil são reconhecidamente restritos. Em 
todo caso, Lula tinha a intenção de implementar uma política externa mais pragmática e menos "presidencial” que a do presidente Fernando Henrique Cardoso, dando mais prioridade ao Mercosul e ao processo de integração regional na América do Sul, vistos por ele como essenciais nas negociações da Alca (como aliás já eram na administração anterior).

O novo realismo diplomático ficou bastante evidente no discurso de posse, feito no Congresso Nacional, em $1^{\circ}$ de janeiro de 2003, ${ }^{12}$ quando o presidente sublinhou os elementos constitutivos e as principais diretrizes da sua política externa:

No meu governo, a ação diplomática do Brasil estará orientada por uma perspectiva humanista e será, antes de tudo, um instrumento do desenvolvimento nacional. Por meio do comércio exterior, da capacitação de tecnologias avançadas, e da busca de investimentos produtivos, o relacionamento externo do Brasil deverá contribuir para a melhoria das condições de vida da mulher e do homem brasileiros, elevando os níveis de renda e gerando empregos dignos.

Destacou então as áreas selecionadas como prioritárias para a atuação da diplomacia profissional:

As negociações comerciais são hoje de importância vital. Em relação à Alca, nos entendimentos entre o Mercosul e a União Européia, e na Organização Mundial do Comércio, o Brasil combaterá o protecionismo e tratará de obter regras mais justas e adequadas à nossa condição de país em desenvolvimento. Buscaremos eliminar os escandalosos subsídios agrícolas dos países desenvolvidos que prejudicam os nossos produtores privando-os de suas vantagens comparativas. Com igual empenho, esforçaremo-nos para remover os injustificáveis obstáculos às exportações de produtos industriais. Essencial em todos esses foros é preservar os espaços de flexibilidade para nossas políticas de desenvolvimento nos campos social e regional, de meio ambiente, agrícola, industrial e tecnológico.

Em seu discurso de posse como novo chanceler, por sua vez, Celso Amorim destacou posições similares: "Participaremos empenhadamente das diversas negociações comerciais movidos pela busca de vantagens concretas, sem constrangimento de nos apresentarmos como país em desenvolvimento e de reivindicarmos tratamento justo”; “Combateremos práticas protecionistas que tanto prejudicam nossa agricultura e nossa

\footnotetext{
${ }^{12}$ Todos os pronunciamentos do presidente podem ser encontrados no website da Presidência da República (www.planalto.gov.br) ou no site da Radiobrás (www.radiobras.gov.br).
} 
indústria"; "Reforçaremos as dimensões política e social do Mercosul, sem perder de vista a necessidade de enfrentar as dificuldades da agenda econômico-comercial, de acordo com um cronograma preciso"; e "Consideramos essencial aprofundar a integração entre os países da América do Sul nos mais diversos planos”. ${ }^{13}$

Os principais problemas da agenda externa do Brasil, nem todos situados no campo exclusivo da diplomacia profissional, pareciam ser, ao início do novo governo: o restabelecimento da confiança na capacidade do Brasil em continuar uma inserção de caráter positivo na economia internacional - o que basicamente significa capacidade de pagamentos externos e a ausência de qualquer ameaça de default nas obrigações financeiras -, a continuidade da participação nos diversos foros negociadores de caráter comercial - Alca, Mercosul-UE e sobretudo rodada da OMC -, a recomposição das condições de funcionamento pleno do Mercosul -fragilizado por diversas inadimplências dos próprios países membros em relação aos requisitos de sua união aduaneira, teoricamente em vigor, mas de fato pouco operacional - e uma série de outros problemas tópicos que podem acarretar custos temporários ou desviar energias em relação aos temas relevantes daquela agenda (como problemas políticos ou de segurança na Venezuela, na Colômbia, na Bolívia ou no Paraguai).

No tratamento operacional da diplomacia, a retomada de alguns grandes temas da ação externa do Brasil também foi evidenciada, como registrado na primeira mensagem do presidente ao Congresso Nacional, em 17 de fevereiro de 2003: "Nas viagens que fiz ao exterior, reafirmei alguns compromissos do nosso país. Em primeiro lugar, o de defesa da paz e de uma ordem mais justa entre as nações ricas e pobres do planeta. Em segundo, o de buscar a reconstrução do Mercosul e a união dos países do nosso continente para obtermos uma inserção soberana no mundo globalizado”. ${ }^{14}$

De novidade, mesmo, na primeira mensagem ao Congresso, registrou-se a decisão de enfatizar as relações do Brasil com a África e de ampliar a presença do Brasil naquele continente. Em relação ao Mercosul, foi apontada a necessidade de que o bloco possa

\footnotetext{
${ }^{13}$ Ver o discurso proferido pelo embaixador Celso Amorim por ocasião da transmissão do cargo de ministro de Estado das Relações Exteriores, “Informação à Imprensa nº 002”, $1^{\circ}$ de janeiro; disponível no website do Itamaraty: www.mre.gov.br.

${ }^{14}$ Ver a "Mensagem ao Congresso Nacional”, 17 de fevereiro de 2003; as seções relativas à defesa e à política externa estão disponíveis no seguinte link da Presidência da República: http://www.presidencia.gov.br/publi_04/COLECAO/mens03_10.pdf.
} 
passar a dispor de "instituições mais permanentes e ganhe solidez jurídica”, sem porém a indicação conseqüente das medidas concretas para concretizar tal proposta, salvo a menção do apoio à “criação de um Instituto Monetário que realize estudos sobre as tarefas necessárias para que o Mercosul venha a ter uma moeda comum” e o início dos estudos para a constituição de seu parlamento (alegadamente por voto direto). Em relação ao processo de integração, tratava-se, sem dúvida, de um dos temas mais relevantes da política externa brasileira e o mais suscetível de mobilizar a atenção dos planejadores nas várias esferas da política econômica nacional e setorial, nos âmbitos comercial, industrial, agrícola e tecnológico, com impacto sobre o modelo de desenvolvimento econômico e social do Brasil.

\section{No governo: em busca de um "novo eixo de poder mundial" e de uma "nova geografia do comércio internacional”}

A diplomacia do governo Lula não se contentaria em simplesmente participar de processos negociatórios nos planos regional, hemisférico ou multilateral, nem pretendia ocupar-se apenas com a administração do déjà vu ou com a manutenção do status quo nas relações internacionais. Extremamente ambiciosa, ela pretendia vôos bem mais altos, oportunamente identificados com a própria mudança no “eixo de poder mundial” ou com a alteração nas correntes de comércio, como diversas vezes manifestado pelo próprio presidente, geralmente em discursos de improviso, à margem dos textos cuidadosamente preparados pelo Itamaraty.

O governo Lula retomou, ampliou e, talvez, exacerbou algumas das políticas que vinham sendo implementadas pela diplomacia presidencial do governo anterior, em especial o vínculo entre uma postura mais afirmativa na região e uma atuação ampla em direção dos países em desenvolvimento, de uma forma geral, em especial com parceiros privilegiados no assim designado "Sul” - que parece incluir a China também -, todos eles conclamados a inaugurar uma "nova geografia do comércio internacional”. O governo FHC já tinha destacado sua intenção - materializada em visitas oficiais ou de trabalho de reforçar os laços diplomáticos, comerciais, tecnológicos e estratégicos com alguns parceiros selecionados numa esfera não hegemônica do poder mundial, como poderiam 
ser a África do Sul, a Índia, a China e a Rússia. Mas as relações com esses países, alguns deles potências nucleares, estavam concebidas em sua dimensão própria, com agendas bilaterais conformadas em função das interfaces mais adequadas ao perfil do relacionamento com o Brasil. O que o governo Lula faz, de imediato, é designá-los como "parceiros estratégicos”, para, a partir daí, passar a definir uma agenda de visitas, consultas e tentativas de coordenação de posições cujo objetivo era o de explicitamente realizar a promessa de mudança nos eixos políticos e econômicos do poder mundial.

A intenção foi imediatamente concretizada pois que, no próprio dia da posse e inauguração do mandato, foram mantidas conversações com os chanceleres da República da África do Sul e da Índia e decidida a criação de um G-3, rapidamente designado como IBAS (sigla dos três países) e dirigido não apenas à cooperação trilateral mas também para atuação conjunta em foros multilaterais. No plano operacional, e no próprio mês de janeiro, retomou-se a diplomacia presidencial que já vinha sendo praticada com certa desenvoltura na administração anterior, com visitas agendadas ao exterior e várias outras sob a forma de convites a Brasília.

A recuperação desse tipo de prática ficou ainda mais evidente a partir da decisão de Lula de participar, de forma quase simultânea, dos foros de Porto Alegre e de Davos, logo ao início de seu governo, abrindo a perspectiva de que o Brasil contribuísse para tentar unificar, numa única agenda do desenvolvimento, as dimensões sociais e econômicas das políticas públicas adotadas nos planos nacional, regional e internacional. A mensagem de Lula em ambos os foros foi praticamente a mesma, cabendo em todo caso registrar a cobrança mais enfática, feita no Foro Econômico Mundial, de um maior engajamento dos países avançados e dos organismos multilaterais com uma solução duradoura para os problemas da miséria e marginalidade que ainda afligem parte substancial da humanidade. No mesmo sentido, e com mensagem similar, ocorreu a participação de Lula, atendendo ao convite do presidente francês, na reunião do G-8, realizada na cidade de Evian no mês de junho de 2003.

A partir daí, o ativismo presidencial e a capacidade de articulação da diplomacia profissional tiveram sua atenção concentrada na constituição de um "fundo mundial contra a fome”, a ser sustentado em algum mecanismo de taxação compulsória das transações financeiras internacionais - ao estilo da "Tobin Tax", preferida pelo pessoal 
do Fórum Social Mundial -, iniciativa depois transformada em uma simples "ação mundial contra a fome e a pobreza”, sem que suas fontes de financiamento fossem claramente identificadas. O episódio da invasão do Iraque pelos Estados Unidos também serviu para nova demonstração de ativismo presidencial e diplomático, com intensas articulações nas semanas que precederam a ação americana, sobretudo no plano bilateral em direção da França, da Alemanha e da Rússia, países mais diretamente envolvidos no complexo jogo de bastidores da decisão que deveria ser tomada pelo Conselho de Segurança das Nações Unidas.

\section{O projeto mais ambicioso: o Mercosul ampliado como base da liderança regional}

A diplomacia regional, na qual se insere a política de integração, é certamente a área da política externa que mais distingue o governo Lula. Ela vem sendo marcada, de um lado, pela intensificação das ações que tinham sido iniciadas em administrações anteriores, ainda que com ênfase e estilo diferentes, e, de outro, pela adoção de posturas condizentes com os valores e prioridades do PT enquanto típico movimento da esquerda latino-americana. Os dois processos não são incompatíveis entre si, antes se completam, pois a diplomacia brasileira já vinha dando grande atenção à política externa regional e tinha no Mercosul um dos vetores essenciais de nossa inserção regional e internacional, assim como, por outro lado, o PT sempre colocou a integração regional como um dos pontos centrais de sua "política externa".

A primeira mudança observada nessa área foi no sentido de deixar discretamente de lado, tanto quanto possível, o velho conceito (essencialmente político) de América Latina em favor do novo conceito de América do Sul, geograficamente mais focado e dotado de um conteúdo econômico-comercial mais preciso, inclusive em suas derivações logísticas. Ela vinha sendo feita desde o governo Itamar Franco - tendo sido inaugurada, na prática, por FHC enquanto chanceler - mas foi incorporada pelo PT e pelo novo governo sem maiores questionamentos, ainda que sem elaborações conceituais tampouco. O foco da todas as articulações passou a ser o Mercosul, considerado o elemento central da estratégia de integração econômica e de articulações políticas, a partir do qual seria possível estabelecer um processo de coordenação de posições com vistas a diversos 
objetivos tidos como prioritários pelo partido e pelo governo. Tratava-se, em primeiro lugar, de reforçar o próprio Mercosul, dotando-o de maior conteúdo social e político, ao lado de suas tradicionais vertentes econômico-comerciais. Impunha-se, em segundo lugar, vincular mais estreitamente o Mercosul a parceiros regionais - e mesmo de fora da região -, de molde a convertê-lo em uma base sólida para negociações comerciais na própria região e no plano mundial.

Em relação ao primeiro objetivo, o governo Lula retomou uma agenda que estava largamente conformada desde o período anterior, tendente a superar os diversos óbices ao acabamento do Mercosul enquanto zona de livre-comércio e enquanto união aduaneira, sob a forma de uma lista de "tarefas inconclusas" à qual foi dado o título de "Mercosul 2006" (por acaso coincidente com o final do governo, ou de seu primeiro mandato). A lista em si não comportava muitas novidades, uma vez que esses obstáculos estavam há muito identificados, mas o fato é que não se definiu uma metodologia específica para o levantamento das dificuldades conhecidas, ademais de generalidades retóricas do tipo "políticas setoriais comuns", "integração de cadeias produtivas" ou "reforço da institucionalidade do Mercosul”. A isso se incorporaram, de modo algo leviano, temas como "moeda comum" ou parlamento do Mercosul, sem maiores conseqüências porém.

Numa primeira fase do governo Lula, a vontade política sobrepunha-se a qualquer visão realista do processo, como expresso no comunicado conjunto dos presidentes do Brasil e da Argentina, Lula e Duhalde, por ocasião de visita de trabalho efetuada por este último a Brasília logo no dia 14 de janeiro de 2003: “Os Presidentes destacaram que o Mercosul constitui um projeto estratégico. Decidiram aprofundar a liberalização dos fluxos de comércio intrazona, a consolidação da União Aduaneira e avançar em direção ao Mercado Comum”. O mesmo comunicado enfatizava a decisão de se criar um parlamento comum, "em prazo relativamente breve”, como sublinhou o presidente Lula em seu discurso de saudação.

Ainda no período imediatamente posterior à eleição e posse do presidente Nestor Kirchner, em 2003, os dois países mantiveram um nível razoável de consultas e de entendimentos sobre temas de interesse comum, a ponto de ambas as chancelarias terem concebido e divulgado um documento de política econômica intitulado pretensiosamente de "Consenso de Buenos Aires”, em nítido contraste e aberta oposição aos dez pontos do 
Consenso de Washington original ${ }^{15}$. Seja como for, a postura discreta assumida pelo Brasil no episódio das negociações com o FMI e com os credores comerciais em torno da moratória e da divida externa da Argentina precipitou nesse país uma espécie de ofensiva crítica contra os interesses econômicos brasileiros, individualmente ou no Mercosul, com o que o bloco comercial passou a estar politicamente fragilizado e economicamente incapacitado de conduzir suas negociações externas - com a União Européia e no âmbito da Alca -, ademais de tornar virtualmente impossível o atingimento das metas constantes do documento "Mercosul 2006” que o governo brasileiro vinha esforçando-se para tornar realidade.

O que se assistiu, na verdade, nas semanas e meses seguintes, foi, ao contrário do desejado pelo administração Lula, um recrudescimento das demandas argentinas por maior proteção em relação à concorrência das indústrias brasileiras nos mercados locais, com a imposição pelo governo argentino de "salvaguardas" setoriais que não tinham nenhum respaldo nos compromissos de liberalização já consolidados e que, de fato, derrogavam ao espírito e à letra do Tratado de Assunção. Tentativas repetidas do governo brasileiro no sentido de demonstrar "compreensão" e "generosidade" em relação às medidas arbitrárias argentinas não redundaram, como talvez esperado, num arrefecimento da demanda por restrições comerciais unilaterais, mas, inversamente, em novas imposições ou ameaças de restrições setoriais adicionais por parte da indústria local. Tão flagrantemente contrárias às regras da zona de livre-comércio do Mercosul foram as medidas argentinas que elas chegaram a colocar os setores brasileiros atingidos em conflito com o Itamaraty e o próprio governo, acusados de excessiva leniência para com o protecionismo argentino, a ponto de setores representativos da indústria brasileira chegarem a aventar a hipótese, diplomaticamente irrealista, de revisão radical do Mercosul e sua retrocessão a fases menos ambiciosas de integração.

A despeito das desavenças comerciais e frustrações bilaterais, e outros pequenos contratempos na coordenação intra-Mercosul - inclusive em relação às negociações da Alca - o Mercosul foi preservado enquanto construção progressiva de um espaço

\footnotetext{
${ }^{15}$ Para uma análise desse documento, ver Paulo Roberto de Almeida, “'Una sombra pronto seras...': Idealpolitik e o Consenso de Buenos Aires”, revista O Debatedouro (Brasília: ano II, n 38, 23 novembro 2003; ISSN 1678-6637; pp. 26-29); disponível no link: http://www.odebatedouro.com.br/edicoes/debat38.pdf.
} 
econômico comum, e não há sinais de que ele possa vir a ser sacrificado deliberada ou conscientemente por alguma liderança política do bloco sub-regional em algum momento do futuro próximo. Mesmo a concretização eventual de “uma” Alca num prazo mais ou menos curto de tempo - entre 2006 e 2007, possivelmente e, em todo caso, não mais no ambicioso formato abrangente e incondicionalmente multilateralista, como concebido em Miami em 1994 - não parece colocar em risco a sobrevivência do Mercosul enquanto mecanismo flexível de coordenação política, ainda que seus aspectos exclusivamente comerciais possam vir a ser parcial ou amplamente afetados pelo grau de concessões no plano econômico oportunamente concertados no âmbito da Alca. Em outros termos, o Mercosul ainda oferecerá uma plataforma para diversos tipos de exercício diplomático, ainda que os desentendimentos Brasil-Argentina tenham diminuído significativamente seu grau de legitimidade e de credibilidade internacionais.

\section{O fardo da liderança: a integração sul-americana}

Uma das características da diplomacia partidária do governo Lula é a “vocação” a que o Brasil se apresente como um dos líderes dos países em desenvolvimento, de molde a congregar esforços e capacidade de manobra no âmbito multilateral, objetivando alcançar as mudanças que o partido e o governo consideram desejáveis ou necessárias no sistema político - o “eixo de poder” - e no econômico - a "nova geografia do comércio internacional”. Essa "vocação", mais autoproclamada do que efetivamente demandada, vem sendo exercida basicamente no âmbito regional sul-americano, embora dela não estejam excluídas outras regiões e países, em especial a África lusófona. A intensidade de contatos diretos - evidenciada tanto pelas viagens empreendidas em todos os países da região, como nas visitas recebidas de quase todos os líderes dos países vizinhos constitui, em todo caso, prova suficiente do engajamento pessoal do presidente na assunção dessa nova frente de trabalho da diplomacia brasileira, como se pode constatar pelo quadro de visitas e viagens bilaterais (e alguns encontros pluri e multilaterais) no plano hemisférico (in fine).

Parcialmente explicada pelo peso econômico específico do Brasil, pela sua extensão geográfica e dimensão do mercado interno, era natural que essa "vocação" 
recebesse acolhimento positivo por parte de alguns países menores, compreensivelmente em busca de vantagens econômico-comerciais e de algum financiamento facilitado para obras de infra-estrutura. Mas ela haveria de se chocar com a visão dos países maiores, a começar pela própria Argentina, cujos interesses se situam, justamente, numa situação regional que afaste qualquer perspectiva de "hegemonia brasileira”, na região e além dela. O México, de certo modo, igualmente entretém a mesma postura “controladora” dos atos, gestos e palavras da diplomacia brasileira, em parte como resultado de seu novo ativismo diplomático desde o início da gestão Fox, mas também derivada da mesma percepção mantida pela Argentina sobre a perda de prestígio relativo se e quando o Brasil viesse a assumir posição protagônica enquanto liderança regional reconhecida no plano mundial. Dois exemplos, dentre vários outros eventos ou processos, podem ser citados nesse particular: a pretensão do Brasil em assumir uma cadeira permanente no Conselho de Segurança das Nações Unidas e a formação de uma comunidade sul-americana de nações, com objetivos tanto econômicos quanto políticos e estratégicos. Diversos outros temas, freqüentam a agenda de qualquer candidato à liderança regional, como o problema da instabilidade política e social em vários países da região, com reflexos para a manutenção do sistema democrático, a questão da guerra civil colombiana, que vem aliada ao narcotráfico e ao crime organizado, os desafios representados por regimes populistas ao estilo de Chávez, na Venezuela, sem mencionar o longuíssimo isolamento de Cuba da maior parte das atividades de cooperação e de integração no hemisfério.

Ao se posicionar, de maneira explícita, como um “líder natural” na região - o que nunca tinha sido sequer aventado pela diplomacia profissional ou admitido de modo aberto pelas administrações anteriores -, o governo do PT abriu uma nova "frente de trabalho” para essa diplomacia, para o sistema econômico e o de segurança do Brasil, “frente” que passou a comportar, obviamente, determinadas vantagens no plano político, mas também certo “fardo imperial”, de contornos ainda indefinidos, para os aparelhos de segurança e para os agentes econômicos, mesmo os da esfera privada. Liderança regional, basicamente, requer dois principais elementos: excedentes financeiros e outros recursos materiais, para fins de cooperação e assistência técnica - evidentemente de caráter não recíproco - e capacitação militar e de segurança dotada de autonomia operacional e de sustentação nos chamados “excedentes de poder”, de maneira a estar habilitado em 
qualquer tempo e lugar, não necessariamente "projetar força” mas, a intervir em crises tópicas e participar de outros processos mais sistêmicos para garantir a segurança e a estabilidade nessa região.

Ora, o Brasil é notoriamente um país apenas parcialmente capacitado a cumprir essas duas funções básicas da chamada liderança - que alguns preferem chamar de “hegemonia” -, seja em prover recursos de natureza assistencial ou cooperativa para parceiros mais pobres, seja em dispor de forças em número e qualidade suficientes para ações de intervenção sob a égide multilateral (peace keeping ou peace making). Nesse sentido, a proclamação unilateral do status de "líder" faria supor que o Brasil estaria em condições de assumir certas responsabilidades, com os encargos correspondentes, em relação aos diferentes problemas da agenda regional. Essa disposição está vinculada, de forma estrutural, à já mencionada candidatura a um assento permanente no CSNU, pretensão que vem recebendo apoio de muitos parceiros na região e fora dela, mas que tem despertado aberta oposição na Argentina e uma postura negativa, mas mais discreta, por parte do México.

Registre-se que o Brasil nunca colocou sua aspiração como sendo parte de algum tipo de representação regional, no quadro da qual ele teria um suposto "mandato" dos países vizinhos para cumprir tarefas que tivessem recebido alguma espécie de "endosso regional” (ou “minilateralista”), após consultas formais ou informais. A primeira questão a ser levantada no plano da diplomacia regional do governo Lula em relação a essa questão é, portanto, a da capacidade brasileira em equacionar a oposição argentina (e, em menor grau, mexicana), mantendo com o país vizinho um diálogo fluído sobre esse assunto de maneira a evitar uma possível ação de obstrução política, em coordenação com outros países. Em todo caso, se e quando ocorrer a ampliação do CSNU, com a provável ascensão do Brasil a essa cadeira "regional” adicional, os problemas de coordenação política e de entendimento com os países vizinhos, a começar pela Argentina, continuarão sendo colocados de modo contínuo.

No que se refere à constituição de um espaço integrado na América do Sul, objeto de declaração presidencial firmada no Peru, em dezembro de 2004, instituindo a Comunidade Sul-Americana de Nações, cabe o registro de que o Brasil foi um dos países que mais intensamente se empenhou para concretizá-la. A “Casa” deve, em princípio, 
retomar a agenda de trabalho do secretariado técnico do IIRSA, a iniciativa de infraestrutura regional sul-americana, que resultou do encontro de presidentes da América do Sul, em Brasília, em setembro de 2000, cuja função era estudar a questão da interligação física. Surpreendentemente, além do brasileiro, nenhum dos demais presidentes do Mercosul viajou ao Peru para participar do lançamento da nova entidade integracionista latino-americana, cuja missão, segundo o líder venezuelano Hugo Chávez seria a de substituir tanto o Mercosul quanto a CAN, o que obviamente não recolhe o assentimento brasileiro. Não se encontram ainda muito bem definidas, as funções e métodos de trabalho da Casa, pois não parece ainda haver acordo completo entre os doze membros sobre importantes questões de funcionamento da entidade.

Em principio, a Casa se propõe, genericamente, lutar contra a pobreza, assegurar educação e defender a paz e a democracia, com um foco principal na criação de um "espaço sul-americano integrado nos terrenos político, social econômico, ambiental e de infra-estrutura”. A despeito de que se pretende realizar a convergência do Mercosul, da CAN, ademais do Chile, da Guiana e do Suriname, os presidentes não firmaram um tratado de criação de uma nova entidade, mas uma simples declaração contendo esses objetivos. Encontros posteriores de altos funcionários e de chanceleres deverão definir um plano de ação, suscetível de merecer a aprovação dos presidentes em um novo encontro, a ser realizado no Brasil.

A diplomacia do governo Lula atribui enorme importância a essa iniciativa, uma vez que ela pode contribuir para reforçar o Mercosul e o próprio papel do Brasil nos esforços de interligação física do continente, projetos cujo financiamento seria operado conjuntamente pelas entidades já existentes - BID, CAF, Fonplata - ou por alguma nova a ser criada, com o apoio do BNDES brasileiro (que aliás já vem apoiando, nos países vizinhos, projetos que contam com participação de empresas brasileiras). Não deixa de ser sintomático, entretanto, que os presidentes dos outros três países membros do Mercosul não tenham comparecido ao encontro fundacional, revelando as tensões e os desencontros atualmente existentes no seio do bloco do cone sul.

Até meados de 2005, todo o esforço de concretização do novo “espaço integrado” era representado por uma rede tênue de acordos de alcance parcial - no conceito “aladiano” da palavra - entre o Mercosul e cada um dos países remanescentes da CAN, 
uma vez que a Bolívia já era um país “associado” ao Mercosul desde 1996 e o Peru, com um acordo similar de liberalização comercial, adquiriu tal status em 2003. Não obstante a conclusão formal dessa rede de acordos entre o Mercosul e a CAN - prometida desde 1998, pelo menos - seria difícil concluir que o processo está em vias de acabamento, uma vez que o potencial de criação de novos fluxos de comércio é, manifestamente, restrito, que as muitas exceções bilateralizadas tornam difícil sua administração aduaneira e que, mais importante, os prazos envolvidos na desgravação de setores sensíveis - definidos com grande latitude setorial - e a indefinição quanto a outros campos possíveis de integração tornam praticamente irrelevantes esses acordos de "liberalização", a ponto de ser legítimo perguntar se eles são de fato a base de uma zona de livre-comércio na região.

Outros testes para a diplomacia brasileira na região são constituídos pelo velho problema da guerra civil na Colômbia e pelos novos riscos políticos associados ao estilo de governar do líder venezuelano Hugo Chávez, confrontacionista em relação aos EUA e de certa forma complacente vis-à-vis os movimentos ditos progressistas da região. No que se refere ao primeiro problema, registre-se o descompasso entre a postura do Brasil disposto a servir como mediador em um hipotético diálogo entre o governo legítimo de Bogotá e os líderes guerrilheiros das FARC, mas relutante em classificar esse grupo como terrorista, como solicitado pelo governo colombiano - e as posições dos governos colombiano e dos EUA, empenhados em desmantelar as bases da guerrilha, hoje convertida em uma "indústria de seqüestros” e em alavanca essencial do tráfico de drogas e do crime organizado. No que tange ao líder venezuelano, as boas relações mantidas entre os dois países, Brasil e Venezuela, contrastam com a deterioração progressiva do relacionamento diplomático entre o país andino e alguns dos seus vizinhos e parceiros, a começar pelos EUA. Ambos os problemas revelam a limitação de meios e instrumentos diplomáticos, econômicos e militares para que o Brasil possa influir, de modo decisivo, num encaminhamento positivo dessas crises e focos de instabilidade.

Aparentemente indiferente a essa baixa capacidade operacional - ou até mesmo política - do Brasil, o presidente Lula anunciava, ainda no começo de maio de 2005, que o Brasil “não abrirá mão de cumprir seu papel de integração” dos países da América do Sul. A justificativa do presidente Lula para o exercício da liderança se apóia, antes de mais nada, na própria vontade política do país, e de seu governo, no sentido de se buscar 
o comprometimento de recursos nacionais para a prestação de assistência não recíproca: “Como maior economia, como maior população, como país de maior potencial científico e tecnológico, nós temos obrigação de estar dando condições para que esse crescimento não se dê apenas dentro do Brasil, mas para que ele se dê, sobretudo, nos países que fazem fronteira conosco” (“conversa” radiofônica do presidente Lula, transmitida em $1^{\circ}$ de maio de 2005). Em outros episódios de instabilidade, como nas crises políticas da Bolívia e do Equador, em 2004 e 2005 respectivamente, o papel do Brasil foi bem mais modesto do que a movimentação dos meios de comunicação deixa supor, contrastando com o forte engajamento na questão do Haiti, na qual o envio de tropas brasileiras foi precedido de contatos intensos com dois membros do CSNU, EUA e França.

\section{No meio do caminho tinha uma pedra: o problema da Alca}

Um dos problemas mais incômodos para o governo do PT, em vista das posições anteriores assumidas pelo partido em relação ao exercício hemisférico de negociações comerciais, foi o de como conduzir o processo negociador da Alca sem confrontar diretamente os EUA, mas também sem descontentar suas bases políticas e sociais, que viam no projeto de zona hemisférica de livre comércio um verdadeiro atentado à soberania brasileira e à faculdade do governo determinar o que se convencionou chamar de “espaços nacionais para políticas de desenvolvimento”. O governo FHC, que tinha seguido o processo desde o seu início, nunca ostentou grande entusiasmo a respeito do projeto americano, mas tampouco mantinha uma oposição de princípio à tentativa de constituição de uma área de livre comércio das Américas. O PT, em contraste, sempre se opôs, de maneira até virulenta, ao que se apresentava, segundo sua visão, como um esquema velado de dominação imperial.

O governo Lula, de forma surpreendente para setores da esquerda, operou uma aceitação muito relutante do princípio do livre comércio e, no plano operacional, passou a comandar uma barganha muito dura na mesa de negociações, o que levou a vários impasses negociais (por certo facilitados pela postura intransigente dos EUA no que respeita o acesso aos seus próprios mercados e à limitação do subvencionismo agrícola). Algumas propostas lançadas pelo Brasil não chegaram sequer a ser explicitadas 
concretamente, como o pedido de compensações para corrigir assimetrias estruturais. Em contraste com a administração anterior, a postura diplomática deixou o lado das negociações meramente “técnicas” para enfatizar o chamado "interesse nacional”, com uma visão bem mais crítica das vantagens e desvantagens da liberalização comercial numa situação de assimetria com o principal parceiro. Mas também se deixou a defesa do multilateralismo e do "entendimento único”, que eram dois pontos enfatizados pelo Brasil anteriormente (na conferência de Belo Horizonte, por exemplo), para uma escolha pela geometria variável, pelo minilateralismo e pela liberalização à la carte, o que de certa forma é compreensível, tendo em vista a própria fragmentação e diferenciação das ofertas dos EUA no esquema da Alca.

De fato, os negociadores americanos recusavam negociar no plano hemisférico questões ditas sistêmicas, como agricultura, antidumping ou subsídios (que são remetidos ao âmbito multilateral da Rodada Doha, da OMC), ao mesmo tempo em que insistiam em manter dentro da Alca questões sistêmicas como propriedade intelectual, concorrência, investimentos, compras governamentais (além do importante setor de serviços), nas quais é evidente o interesse maior dos Estados Unidos. Em resposta a essa fragmentação do processo negociador, o Brasil e os países do Mercosul foram igualmente levados a propor a passagem do tratamento de determinados itens da agenda negociadora (investimentos e propriedade intelectual, por exemplo) ao plano multilateral da OMC. Em síntese, os países do Mercosul propunham o seguinte: (a) negociação bilateral (ou seja, 4+1) de acesso a mercado no âmbito da Alca para bens (agrícolas e industriais), serviços, investimentos e compras governamentais; (b) negociação multilateral no âmbito da Alca no que se refere a regras de comércio; e (c) transferência para as negociações multilaterais de Genebra (Rodada Doha) de regras relacionadas a serviços, investimentos, propriedade intelectual, competição.

Depois de um intenso processo de reuniões e consultas bilaterais, Brasil e EUA chegaram a um quase consenso em torno de um formato de acordo que poderia ser designado como de Alca à la carte. Na reunião ministerial de Miami, em novembro de 2003, emergiu o ambíguo entendimento de que o futuro acordo deveria reconhecer "a necessidade de flexibilidade, a fim de que sejam levadas em consideração as necessidades e as sensibilidades de todos os parceiros da Alca”. No aspecto mais importante, a visão da 
Alca esboçada nesse encontro de Miami, conformou a Alca à la carte, ou seja, um núcleo mínimo de regras e obrigações, comuns a todas as partes envolvidas, e conjuntos adicionais de compromissos a serem alcançados por negociações plurilaterais ou mesmo bilaterais.

A despeito do engajamento das delegações e de um intenso processo de consultas, conduzido sobretudo entre os Estados Unidos e o Brasil nos primeiros meses de 2004, não foi possível lograr-se um entendimento minimamente aceitável para todas as partes em torno de um conjunto comum de regras e obrigações que sustentariam o núcleo essencial da futura Alca. Não foi possível, portanto, realizar, até o final de 2004, como originalmente previsto, a consolidação dos resultados da negociação em torno de um acordo hemisférico. Os elementos principais dos desacordos persistentes, sobretudo entre o Brasil e os Estados Unidos, residiam na abrangência desse conjunto de regras mínimas e nas características mesmas do entendimento mínimo aceitável para cada uma das partes. Na visão do Brasil, o mais importante seria superar a discussão sobre normas - que poderiam ser equacionadas no âmbito da Rodada de Doha, da OMC - e passar a uma negociação centrada na troca de ofertas, isto é, enfatizando a questão do acesso a mercados (inclusive em matéria de serviços), terreno no qual o Brasil preferiria um formato “4+1", ou seja, entre os países membros do Mercosul e os Estados Unidos. Os EUA, por sua vez, acompanhados pelo México, pelo Chile e pelo Canadá, insistem no estabelecimento de um espaço econômico caracterizado por regras uniformes, conformando um ambiente de negócios homogêneo, suscetível de dar segurança e possibilidade de ganhos de escala para as empresas, incluindo uma proteção adequada aos investimentos e à propriedade intelectual, os serviços e as compras governamentais.

Os Estados Unidos, à margem e independentemente da Alca, continuaram a negociar acordos de liberalização comercial com outros países e sobretudo com parceiros hemisféricos, como o Chile e os países da América Central, ao passo que o Brasil e seus sócios no Mercosul perseguiram, igualmente, uma estratégia de aprofundamento das relações continentais. Pode-se dizer que a Alca, devido em grande medida à postura dos governos brasileiro e americano, “aladizou-se”, com as vantagens e desvantagens desse tipo de arranjo ad hoc e parcial. Em suma, a conclusão das negociações da Alca, inicialmente prevista para janeiro de 2005, foi delongada a uma data ainda incerta, em 
virtude, entre outros motivos, das inúmeras vinculações entre a temática da Alca e o processo negociador em curso na OMC. As dificuldades maiores se referem, obviamente, às posições contrastantes dos EUA e do Brasil em matéria de protecionismo agrícola e dos chamados itens sistêmicos.

\section{Avaliação tentativa da diplomacia do governo Lula}

No plano mais geral da política externa, o governo Lula sempre proclamou seu desejo de promover uma política externa criativa (definida como "ativa e altiva" por seu chanceler), e acredita que ela tem um papel substantivo na conformação de um "projeto nacional”. Em contraste com a administração FHC, que entretinha um diálogo com outros líderes mundiais, buscando um melhor ambiente cooperativo para o desenvolvimento do Brasil, Lula busca exercer uma liderança regional e internacional para mudar o mundo, de onde resulta a intenção de implantar uma "nova geografia comercial". Os contornos desta última não foram muito bem definidos, mas ela tem a ver com uma presença mais afirmada dos países em desenvolvimento no processo decisório em matéria de negociações comerciais e num acesso desimpedido aos mercados nos quais esses países apresentam nítidas vantagens comparativas (o que, ironicamente, significa uma aceitação plena dos princípios ricardianos, de outra forma recusados por economistas de esquerda).

Numa apreciação final, parece ainda prematuro adiantar possíveis conseqüências dessas mudanças de estilo e mesmo de conteúdo da política externa governamental da administração Lula para o Brasil enquanto ator internacional e regional. A intenção proclamada do novo governo é a de assegurar uma maior presença do Brasil no mundo, garantir-lhe uma cadeira permanente na ONU e tornar sua voz ouvida nas decisões em torno dos grandes problemas da comunidade internacional. Uma busca mais afirmada da liderança regional pode também resultar do novo ativismo regional, mas nesse particular a liderança não pode partir apenas do desejo de quem pretende liderar, mas da aceitação consensual dos liderados presumidos. Este ponto ainda não ficou muito claro na relação que o governo Lula pretende manter com a Argentina, que sempre declarou e entende defender sua concepção de uma relação especial com o Brasil como situada num plano igualitário, não assimétrico. Em todo caso, uma avaliação mais substantiva dos resultados 
efetivos do novo estilo e da nova agenda de trabalho da diplomacia do governo Lula somente será possível após o término de alguns processos negociadores nos quais o Brasil se encontra presentemente engajado e tendo em vista os efeitos práticos da liderança proclamada e auto-assumida no plano regional.

Referências

ALMEIDA, Paulo Roberto de. Uma política externa engajada: a diplomacia do governo Lula, Revista Brasileira de Política Internacional, Brasília, ano 47, n. 1, p. 162-184. 2004. Disponível em: <http://www.pralmeida.org/05DocsPRA/1260PExtLula.pdf>.

. Relações internacionais e política externa do Brasil: história e sociologia da diplomacia brasileira. 2. ed. Porto Alegre: UFRGS, 2004.

. A grande mudança: conseqüências econômicas da transição política no Brasil. São Paulo: Códex, 2003.

. Una sombra pronto seras...: Idealpolitik e o Consenso de Buenos Aires. $\mathbf{O}$ Debatedouro Brasília, ano 2, n. 38, p.26-29, nov. 2003. Disponível em: <http://www. odebatedouro.com.br/edicoes/debat38.pdf $>$.

AMORIM, Celso. Discurso proferido em $\mathbf{1}^{\circ}$ de janeiro pelo embaixador por ocasião da transmissão do cargo de ministro de Estado das Relações Exteriores. Disponível em: <www.mre.gov.br>. (Informação à Imprensa, 2).

BRASIL. Presidência da República. [Home page]. Brasília, 2005. Disponível em: $<$ www.planalto.gov.br>. gov. br>.

. Agência Brasil. [Home page]. Brasília, 2005 Disponível em:<www.radiobras.

. Mensagem ao Congresso Nacional, 17 de fev. 2003: as seções relativas à defesa e à política externa. Brasília, 2003. Disponível em: <http://www.presidencia. gov.br/publi_04/COLECAO/mens03_10.pdf>. 
GARCIA, Marco Aurélio. Assessor da Presidência da República aponta os eixos da política externa do governo Lula. Boletim da ADB, Brasília, ano 10, n. 42, p. 16-22, jan./mar. 2003.

GRUPO DE PESQUISAS EM RELAÇÕES INTERNACIONAIS. A política externa nas plataformas dos candidatos a presidente do Brasil em 1989. Brasília:

Universidade de Brasília, dez.1989. p. 55-56. Texto Processado.

MERCADANTE propõe acordo com os EUA. Gazeta Mercantil, São Paulo, 22 nov. 2002.

PARTIDO DOS TRABALHADORES. [Home page]. São Paulo, 2005. Disponível em: $<$ www.pt.org.br>.

. Programa, manifesto, estatuto. Brasília: Centro de Documentação e Informação da Câmara dos Deputados, 1984, p. 5-7. Manifesto.

. Programa de governo. Teoria e Debate, São Paulo: caderno especial, p. 29-30. n. 24, mar./maio de 1994.

SILVA, Luíz Inácio Lula da. Compromisso com a campanha. Disponível em: <www.lula.org.br>. Acesso em: 29 out. 2002.

. [Home page oficial do candidato Lula]. Disponível em: <www.lula.org.br>.

Brasília, 10 de maio de 2005 


\title{
A diplomacia regional do Presidente Lula Viagens do presidente ao exterior e visitas estrangeiras de alto nível ao Brasil, exclusivamente no contexto americano, de dezembro de 2002 a maio de 2005
}

\author{
2002 \\ (como presidente eleito):
}

1. Diplomacia ativa: visita de cortesia à Argentina (Buenos Aires, 2 dezembro)

2. Diplomacia ativa: visita de cortesia ao Chile (Santiago, 3 dezembro)

3. Reunião a convite do presidente George Bush (Washington, 10 dezembro)

\section{3}

4. Encontro com o presidente da Venezuela, Hugo Chávez (Brasília, 2 janeiro)

5. Encontro com o primeiro ministro da Guiana, Samuel Hinds (Brasília, 2 janeiro)

6. Visita do presidente da Argentina, Eduardo Duhalde (Brasília, 14 janeiro)

7. Posse do presidente Lúcio Gutierrez do Equador (Quito, 15-16 janeiro); Diplomacia ativa: constituição do "grupo de amigos" para ajudar a OEA na crise política da Venezuela (16 janeiro)

8. Visita do presidente da Colômbia, Álvaro Uribe (Brasília, 7 março)

9. Visita do presidente do Peru, Alejandro Toledo (Brasília, 11 abril)

10. Visita do presidente da Venezuela, Hugo Chávez (Recife, 25 abril)

11. Visita do presidente da Bolívia, Gonzalo Sánchez de Lozada (Brasília, 25 abril)

12. Visita do presidente do Uruguai, Jorge Battle (Brasília, 12 maio)

13. Reunião de chefes de Estado do Grupo do Rio, no Peru (Cusco, 24 maio)

14. Posse do presidente Nestor Kirchner (Buenos Aires, 25 maio)

15. Visita do presidente do Equador, Lucio Gutiérrez (Brasília, 27 maio)

16. Visita do presidente da Argentina, Nestor Kirchner (Brasília, 11 junho)

17. Reunião de cúpula do Mercosul (Assunção, 17-18 junho)

18. Visita aos Estados Unidos, com diversos ministros (Washington, 20 junho)

19. Visita bilateral à Colômbia e reunião da Comunidade Andina (Rio Negro, 27-28 junho)

20. Visita do presidente do Suriname, Runaldo Ronald Venetiaan (Brasília, 22 julho)

21. Visita do presidente da Guiana, Bharrat Jagdeo (Brasília, 30 julho)

22. Diplomacia ativa: reunião bilateral Brasil-Paraguai (Foz de Iguaçu, 16 agosto)

23. Visita do presidente do Chile, Ricardo Lagos (Brasília, 19 agosto)

24. Visita de trabalho ao presidente do Peru, Alejandro Toledo (Lima, 24 agosto)

25. Encontro de trabalho com Presidente Hugo Chávez (Caracas e Ciudad Guyana, 27 agosto)

26. Participação na $89^{a}$ sessão do Conselho Internacional do Café e $40^{\circ}$ aniversário da Organização Internacional do Café (Cartagena de Índias, Colômbia, 16 setembro)

27. Diplomacia ativa: visita de trabalho ao México (25 setembro)

28. Visita bilateral a Cuba, encontros com Fidel Castro (Havana, 26-27 setembro)

29. Visita do presidente do Paraguai, Nicanor Duarte Frutos (Brasília, 14 outubro)

30. Visita oficial à Argentina e encontro com presidente Nestor Kirchner (Buenos Aires e El Calafate, Patagonia, 16-17 outubro); Diplomacia ativa: "Consenso de Buenos Aires" (Buenos Aires, 16 outubro)

31. Visita de trabalho à Bolívia (Santa Cruz de la Sierra, 14 novembro)

32. XIII Cúpula Ibero-Americana de Chefes de Estado e de Governo (Santa Cruz de la Sierra, 15 novembro)

33. Visita do presidente da República Dominicana, Hipólito Mejia (Brasília, 17 novembro)

34. Visita do presidente da Guiana, Bharrat Jagdeo (Brasília, 17 novembro)

35. Visita do presidente da Bolívia, Carlos Mesa (Brasília, 18 novembro) 
36. Reunião de cúpula do Mercosul (Montevidéu, 16 dezembro)

2004

37. Reunião extraordinária de cúpula das Américas (Monterrey, 12-13 janeiro)

38. Visita do presidente da Argentina, Nestor Kirchner (Rio de Janeiro, 15-16 março)

39. Diplomacia ativa: $3^{a}$ conferência de cúpula Europa-América Latina (Guadalajara, México, 28 maio)

40. Encontro de trabalho com o presidente da Colômbia, Alvaro Uribe (São Paulo, 21 junho)

41. Diplomacia ativa: Reunião com investidores da América do Norte (Nova York, 24 junho)

42. Visita de trabalho do presidente do México, Vicente Fox (Brasília, 7 julho)

43. Reunião de cúpula do Mercosul (Puerto Iguazu, Argentina, 7-8 julho)

44. Encontro de trabalho com o Presidente Carlos Mesa, da Bolívia (Santa Cruz de la Sierra, 9 julho)

45. Visita de trabalho à Bolívia, inauguração de ponte fronteiriça (Cobija, 11 agosto)

46. Visita ao Paraguai, cerimônia de instalação do Tribunal Permanente de Revisão do Mercosul (Assunção, 13 agosto)

47. Posse do novo presidente da República Dominicana (Santo Domingo, 15 agosto)

48. Diplomacia ativa: Declaração de Santo Domingo, com os presidentes do Uruguai, da Costa Rica, de Honduras, da Guatemala, do Haiti (provisório), de Antigua e Barbusa, dos Países Baixos (Primeiro-Ministros), das Ilhas Turkas e Caicos (Primeiro-Ministros) e da República Dominicana (Santo Domingo, 17 agosto)

49. Visita de trabalho ao Haiti: futebol e missão de paz da ONU; encontro com o presidente Boniface Alexandre (Porto Príncipe, 18 agosto)

50. Visita oficial ao Chile, encontro com presidente Ricardo Lagos (Santiago, 23 e 24 agosto)

51. Visita de Estado ao Equador (Quito, 25 agosto)

52. Visita de trabalho do presidente da Venezuela, Hugo Chávez (Manaus, 15 setembro)

53. Abertura da $59^{a}$ Assembléia Geral da ONU (Nova york, 21 setembro); encontro com o presidente da Argentina, Nestor Kirchner

54. 18 18 Cúpula do Grupo do Rio (Rio de Janeiro, 4-5 de novembro)

55. Reunião de Cúpula Ibero-Americana (São José, Costa Rica, 19-20 novembro)

56. Terceira Reunião de presidentes sul-americanos para a criação da Comunidade Sul-Americana de Nações (Ayacucho, Peru, 9 dezembro)

57. Reunião de cúpula do Mercosul (Ouro Preto, MG, 16 dezembro)

2005

58. Encontro com Presidente da Colômbia, Álvaro Uribe (Letícia, 19 janeiro)

59. Visita oficial à Venezuela, encontro com o presidente Hugo Chávez (Caracas, 14 fevereiro)

60. Visita à Guiana, encontro com o presidente Bharrat Jagdeo (Georgetown, 14 fevereiro)

61. Visita ao Suriname, participação na $16^{a}$ Conferência de Chefes de Governo da Comunidade do Caribe (Paramaribo, 15 fevereiro)

62. Posse do Presidente Tabaré Vasquez, do Uruguai (Montevidéu, $1^{\circ}$ março)

63. Visita do presidente de Honduras, Ricardo Maduro (Brasília, 4 maio)

64. Reunião de cúpula entre países sul-americanos e países árabes (Brasília, 10-11 maio)

Fontes: Dados coletados pelo autor em diversos sites oficiais (Presidência da República, Agência Brasil da Radiobrás e Ministério das Relações Exteriores). Não existe uma única informação pública, agregada e exclusiva, sobre eventos diplomáticos envolvendo o presidente da República (todos os sites citados são lacunares, incompletos e parciais).

Atualizado em 10 de maio de 2005 